\title{
Current status of terrestrial mammals on Jeju Island
}

\author{
Yeong-Seok Jo ${ }^{1}$, Tae-Wook Kim² ${ }^{2}$ Byeong-Jin $\mathrm{Choi}^{3}$ and Hong-Shik $\mathrm{Oh}^{4, *}$ \\ ${ }^{1}$ National Institute of Biological Resources, Incheon 404-170, Korea \\ ${ }^{2}$ Youngsangriver Environmental Management Office, Gwangju 502-788, Korea \\ ${ }^{3}$ Korean Natural Environment Institute, Seoul 122-831, Korea \\ ${ }^{4}$ Cheju National University, Jeju 690-756, Korea \\ *Correspondent: sciedu@jejunu.ac.kr
}

Located $60 \mathrm{~km}$ from southern tip of Korean peninsula, Jeju is the largest Island in Korea and composed of volcanic habitat. Twenty-eight species of terrestrial mammals are listed from Jeju Island, of which 1 species and 3 subspecies are endemic. Also, 1 endangered species and 4 invasive alien species of land mammals are listed. Current status, brief history, management and conservation of the 28 species are discussed.

Keywords: Jeju Island, mammal

\section{INTRODUCTION}

Jeju Island lies in the Korea Strait approximately $60 \mathrm{~km}$ from southern tip of the Korean peninsula (Fig. 1). At $1,849 \mathrm{~km}^{2}$, it is Korea's largest island, and its elliptical shape spans $41 \mathrm{~km}$ north to south, and $73 \mathrm{~km}$ east to west. Human population density on Jeju is approximately 300 per $\mathrm{km}^{2}$ and the island is Korea's best known tourism destination, with 5 world natural heritage sites and a biosphere reserve designated by UNESCO (UNESC, 2012a; 2012b).

Jeju was created from volcanic eruptions approximately 2 million years ago and has been isolated from the mainland since the last ice age 10,000 years ago. With a climate and geological features that differ from those on the Korean peninsula, a distinct flora and fauna has evolved on Jeju.

Although Jeju has a remarkable natural history, the island's mammals are not well-studied. After Thomas (1906; 1908) recorded two subspecies of mammals, only a few mammal studies were conducted by Japanese researchers during Japan's colonization of the island (Won and Woo, 1958; Oh et al., 2007). After the Korean War, Johnson and Jones (1955) recorded 2 subspecies of mice. Recently, systematic mammal surveys on Jeju have been conducted by the National Survey, National Park Survey and local government (Park, 1985; Oh, 2002; Oh, 2006a; 2006b; Oh et al., 2007).

Jeju's unique environment and geographic isolation have influenced the mammal fauna. At least, 4 native species, leopard cat Prionailurus bengalensis, brown bear Ursus arctos, wild boar Sus scrofa and sika deer Cervus nippon have become locally extinct (Table 1), and invasive mammals including Sus scrofa, Sciurus vulgaris, Tamias sibiricus and Myocastor coypus have colonized the island (Table 2). Island populations are vulnerable to invasive species, and therefore, extensive conservation strategies are required for Jeju (Van Dyke, 2008).

Here, we review the current conservation and management information on Jeju's terrestrial mammals.

\section{Order Soricomorpha}

Family Soricidae

\section{Sorex caecutiens hallamontanus, Jeju Shrew}

Discovered by Oh in 1994 (Ohdachi et al., 2003), this is the only Sorex species on Jeju. According to Ohdachi et al. (2005), this species is a subspecies of Sorex caecutiens, but on the Korean peninsula the subspecific status of $S$. c. annexus and $S$. c. macropygmaeus is uncertain (Won and Smith, 1999). S. c. hallamontanus is the largest among the S. caecutiens/shinto group and morphologically similar to $S$. shinto, even though DNA data place this form with S. caecutiens (Ohdachi et al., 2005). The key character of Jeju Shrew is the distinguishable width of the side paracone of the fourth premolar of upper jaw (H.S. Oh, Cheju National University, unpublished report).

S. c. hallamontanus is found between $800-1,400 \mathrm{~m}$ around Halla-san, but its natural history has not been described (Oh et al., 2007). On Korean peninsula, S. caecu- 


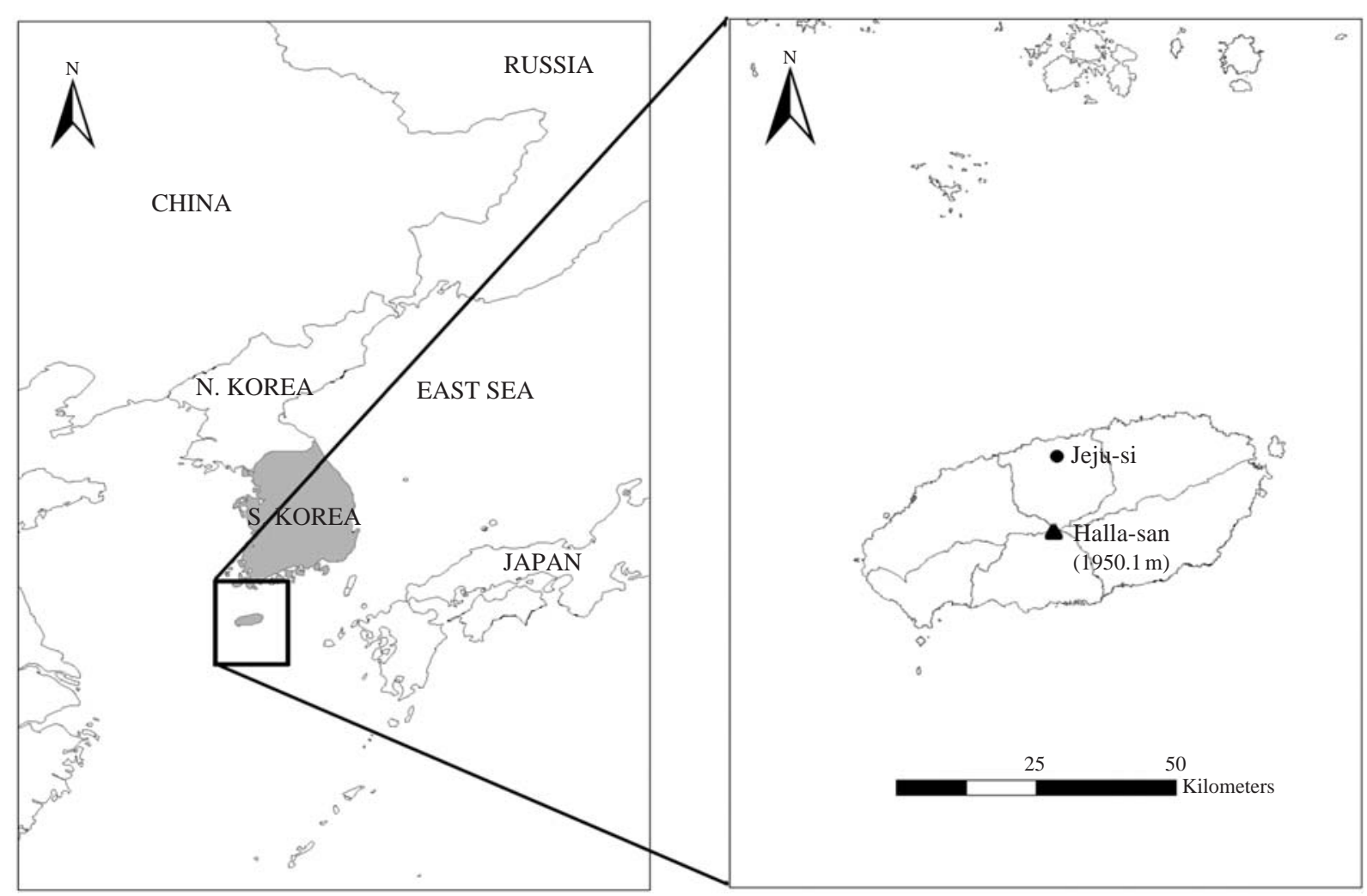

Fig. 1. Map of Jeju Island, Republic of Korea.

Table 1. Extinct mammals on Jeju Island, Republic of Korea.

\begin{tabular}{lll}
\hline \multicolumn{1}{c}{ Species } & Extinction period & \multicolumn{1}{c}{ Remarks } \\
\hline Prionailurus begalensis & $1930 \mathrm{~s}-1940 \mathrm{~s}$ & Last sample acquired by Mori (1928) \\
Ursus arctos & Prehistoric era & Fossil record (Park, 1974) \\
Sus scrofa & Early $20^{\text {th }}$ century & Fossil record (Park, 1974) \\
Cervus nippon & Early $20^{\text {th }}$ century & Fossil record (Park, 1974) \\
\hline
\end{tabular}

Table 2. Invasive mammals on Jeju Island, Republic of Korea.

\begin{tabular}{lcll}
\hline \multicolumn{1}{c}{ Species } & Introduced period & Cause of introduction & \multicolumn{1}{c}{ Current status } \\
\hline Vulpes vulpes & 1987 & Farming & Few escaped but the population never established \\
Sus scrofa & 2003 & Farming & Increasing \\
Cervus nippon & $1992-1993$ & Undesigned restoration & Few remained \\
Sciurus vulgaris & $2000 \mathrm{~s}$ & Human release & Few remained \\
Tamias sibiricus & $1980 \mathrm{~s}$ & Human release & Sustained \\
Myocastor coypus & $1990 \mathrm{~s}$ & Farming & Exterminated around 2000s and reoccurred in 2011 \\
\hline
\end{tabular}

tiens is distributed within montane areas and it is relatively abundant in the north (Won, 1967; Won, 1968; Yoon et al., 2002).

\section{Crocidura shantungensis, Asian Lesser White-Toothed Shrew}

In 1934, Orii collected this species and Kuroda includ- ed it in C. dsnezumi as a subspecies (Kuroda, 1934; Won, 1967). Jameson and Jones (1977) included C. dsnezumi in C. russula but Corbet (1978) treated C. dsnezumi as a separate species. Iwasa et al. (2001) treated the Jeju population as $C$. suaveolens but confusion with $C$. $d$. quelpartis and $C$. suaveolens may exist (Motokawa et al., 2003). Motokawa et al. (2003) treated the Jeju population as a junior synonym of $C$. shantungensis. However, Jeju ani- 
mals have distinct morphological variations (e.g., larger size) compared to those in the mainland population (Motokawa et al., 2003). Wilson and Reeder (2005) refer to the possibility of subspecies of $C$. shantungensis. There is still controversy over the presence of $C$. dsinezumi on Jeju regardless of $C$. shantungensis. However, only $C$. shantungensis has been captured in recent surveys. Defining the subspecific level of Jeju's population is necessary, unless 2 species in the genus Crocidura exist on the island.

This species inhabits various habitats from lowland to high mountains up to $1,100 \mathrm{~m}$ (Won, 1967; Oh et al., 2007). There is constant home range that widens at the time of breeding season (H.S. Oh, Cheju National University, unpublished report).

\section{Order Chiroptera}

Family Rhinolophidae

\section{Rhinolophus ferrumequinum quelpartis, Greater Horseshoe Bat}

The Jeju population was regarded as a separate subspecies (R. $f$. quelpartis) from the Korean peninsula $(R . f$. korai) but $R$. f. korai could be a synonym of $R$. f. quelpartis based on genetic data (Sim, 1986).

Greater horseshoe bats on Jeju are found to roost in sea caves, montane caves, and tunnels in large groups of 50 to several hundred. It is commonly observed even around villages, and prefers riparian areas in evergreen broadleaf forests (Oh et al., 2007).

Family Vespertilionidae

\section{Pipistrellus abramus, Japanese Pipistrelle}

$P$. abramus has been often regarded as subspecies of P. javanicus (Won and Smith, 1999); however, is now considered a separate species (Wilson and Reeder, 2005).

$P$. abramus is commonly observed around villages, and has been known to occupy Gurin cave, which is on Western Halla-san and known as a volcanic cave located on the highest place in Korea(B.J. Choi, Korean Nature and Environment Institute, Unpublished data).

\section{Hypsugo alaschanicus coreensis, Alashanian Pipistrelle}

Yoshiyuki (1989) treated H. a. coreensis as a distinct species. However, this form was regarded as subspecies of H. savii (Won and Smith, 1999). Horacek et al. (2000) suggested that $H$. s. coreensis might represent a separate subspecies from $H$. savii. Alashanian Pipistrelles were captured in the northern part of Jeju by Choi in the 1980s (B.J. Choi, Korean Nature and Environment Institute, Unpublished data).

\section{Myotis bombinus, Far Eastern Myotis}

M. bombinus was formerly included in $M$. nattereri but treated as a separate species by Kawai et al. (2003).

Far Eastern myotis were captured on the northern part of Jeju and Halla-san in the 1980s and in 2002 (B.J. Choi, Korean Nature and Environment Institute, Unpublished data).

\section{Myotis branditii, Brandt's Myotis}

This species was regarded as Myotis mystacinus gracilis (Yoon and Son, 1989). But Horacek et al. (2000) includes gracilis with $M$. branditii. Brandt's myotis has only been recorded once on Jeju, in the island's southwest (B. J. Choi, Korean Nature and Environment Institute, Unpublished data).

\section{Myotis daubentonii, Daubenton's Myotis}

The Korean population is regarded as $M$. d. ussuriensis (Won and Smith, 1999). This bat inhabits coastal caves or abandoned mines in small groups (Won, 1967).

This species occurs with Myotis macrodactylus in Gurin cave of Jeju (B.J. Choi, Korean Nature and Environment Institute, Unpublished data).

\section{Myotis formosus, Hodgson's Myotis}

All Korean populations of Hodgson's myotis are regarded as M. f. tsuensis (Won and Smith, 1999). Hodgson's myotis is distributed throughout the western part of the Korean peninsula (Yoon, 2010).

On Jeju, a hibernating population has been consistently recorded in Gurin cave (B.J. Choi, Korean Nature and Environment Institute, Unpublished data). Hodgson's bat is the only endangered mammal on Jeju designated by Korean ministry of environment.

\section{Myotis ikonnikovi, Ikonnikov's Myotis}

Ikonnikov's myotis is a monotypic species (Won and Smith, 1999). This species is rare in Korea and no information exists on the ecology of the Korean population (Yoon, 2010).

There are 2 specimens of Ikonnikov's myotis on Jeju, in the north and Halla-san (B.J. Choi, Korean Nature and Environment Institute, Unpublished data).

\section{Myotis macrodactylus, Big-footed Myotis}

Big-footed myotis is widely distributed around Korea. It is one of the most abundant cave bats and will roost with other species. These bats generally inhabit wetlands, hills, and forests.

Around northern Jeju and Gurin cave, the big-footed myotis has been observed in groups of females that foster 
pups (B.J. Choi, Korean Nature and Environment Institute, Unpublished data).

\section{Miniopterus fuscus, Southeast Asian Long-fingered Bat}

Only 1 specimen is known from Korea (Son and Choi, 2001). On July 8, 1986, 1 female was captured by Son and Choi (2001). The distribution of Southeast Asian longfingered bat is Okinawa, Japan. The individual on Jeju is regarded as a vagrant (Son and Choi, 2001).

\section{Miniopterus schreibersii fuliginosus, Schreibers's Long-fingered Bat}

Even though no specimens from Jeju have been examined, M. schreiberii in Korea is considered as M. s. fuliginosus (Yoon, 2010).

This species inhabits various habitats, including river banks, hills, montane forests, and grassland. Hibernacula and breeding caves are distinct. Long-fingered bats move seasonally and females cooperate in breeding and fostering as a group. This species has been found in northern Jeju and Halla-san (B.J. Choi, Korean Nature and Environment Institute, Unpublished data).

\section{Murina leucogaster, Greater Tube-nosed Bat}

Although the Korean population of Greater Tube-nose Bat was regarded as 2 subspecies, $M$. l. inermedia and M. l. ognevi (Yoon, 1994), Yoon (2010) treats subspecies of Korea solely as M. l. intermedia.

There is collection record of greater tube-nosed bat from the northern part of Jeju (B.J. Choi, Korean Nature and Environment Institute, Unpublished data).

\section{Order Carnivora}

Family Mustelidae

\section{Meles leucurus, Asian Badger}

The Korean population of badger was regarded as Meles meles amurensis, but all East Asian populations are now treated as M. leucurus (Abramov, 2001).

Badgers were rare on Jeju, and Kishida and Mori (1931) were not convinced of the species' presence on the island. Won and Woo (1958) collected the first scientific specimen. Jeju's badger population now exceeds that of the Korean peninsula. It is unknown whether the population has increased naturally or as a result of releases from badger farms. Badgers on Jeju inhabit shrub forest and small valleys around hills, and excavate burrows or use holes in rocky areas.

\section{Mustela sibirica quelpartis, Jeju Weasel}

Even though M. s. quelpartis is separate from 2 sub- species (M. s. coreana and M. s. manchurica) on the Korean peninsula, the primary morphological difference is pelage color (Won, 1968). Taxonomic review is needed for M. s. quelpartis (Yoon et al., 2002). According to Won and Woo (1958), a number of weasels on Jeju has been caught by fur trappers. This species occurs around villages, farmlands, and orchards. Also, road-killed weasels are commonly found. This species is distributed from lowland to elevations of about $1,600 \mathrm{~m}$.

$$
\begin{aligned}
& \text { Order Artiodactyla } \\
& \text { Family Suidae }
\end{aligned}
$$

\section{Sus scrofa, Wild Boar}

Thomas (1906) reported wild boar existed on Jeju, even though he did not obtain a sample. Although Mori (1928) referred to the possibility of wild boar on Jeju, Kishida and Mori (1931) doubted wild boar on Jeju. According to Won and Woo (1958), wild boars were extinct. The current population of wild boar on Jeju is believed to be established by escaped individuals from a wild boar farm. Also, genetic analysis on wild boar on Jeju shows that this group is more closely related to Chinese boar than Korean boar (J.G. Oh, Halla-san research Institute, unpublished data).

\section{Family Cervidae}

\section{Capreolus pygargus tianschanicus, Siberian Roe}

Although records exist for both $C$. p. pygargus and $C$. p. tianschanicus (Kishida and Mori, 1931), only samples of C. p. tianschanicus have been collected on Jeju (Won and Woo, 1958).

Siberian roe on Jeju was regarded as $C$. p. bedfordi but was revised as $C$. $p$. tianschanicus based on genetic data (Koh and Yang, 2000). Jeju has the most abundant roe deer population in Korea due to active protection since the 1980s (Won and Smith, 1999; Oh et al., 2011).

This species inhabits all parts of Jeju above $300 \mathrm{~m}$. Also, road-killed individuals are found often. The Siberian Roe is the most common large mammal species on Jeju.

\section{Cervus nippon, Sika Deer}

Sika deer populations in Korea have been regarded as 2 subspecies, C. n. hortulorum and C. n. mantchuricus. The Jeju population was considered as $C$. $n$. mantcuricus (Won, 1967).

Sika deer on Jeju used to be abundant, but became extinct around 1915 (Mori, 1928). In 1992 and 1993, 12 Taiwanese sika deer (C. n. taioanus) were released for restoration in private without scientific planning (Oh et al., 2007). These individuals were present until 2004, but it is unknown if they still persist. The situation is com- 
plicated as several private deer farms operate on Jeju.

Order Rodentia

Family Sciuridae

\section{Sciurus vulgaris, Eurasian Red Squirrel}

Red squirrels were first reported on Jeju by Oh (2006b), however, the subspecific status is unknown. On the Korean peninsula, red squirrels prefer coniferous forest and this is the main pest species of pine cones. According to the National Park rangers, pet squirrels were released around 2000. Red squirrels are thinly distributed in coniferous forests of southern Jeju.

\section{Tamias sibiricus, Siberian Chipmunk}

The Siberian chipmunk was recorded on Jeju by Park (1985) around Sooak-Gyo on the $7 \mathrm{~km}$ South-east of Halla-san. The Jeju chipmunk population may have been established through intentional releases (Oh, 2006b). The population has increased continuously since first detection and chipmunks are observed from lowlands to elevations of $1,300 \mathrm{~m}$.

\section{Family Cricetidae}

\section{Tscherskia triton, Greater Long-tailed Hamster}

Even though the possibility of greater long-tailed hamster on Jeju has existed (Won and Smith, 1999), this species was not captured until 2007. The greater long-tailed hamster was discovered OR first documented/recorded by the mammal laboratory of Cheju National University in 2007 and its presence has been consistently recorded since then. More study on the subspecific status of $T$. triton on Jeju is required.

On Jeju, T. triton inhaibits shaded, damp habitats near streams within dense forest.

\section{Family Muridae}

\section{Apodemus chejuensis, Jeju Striped Field Mouse}

The striped field mouse was first reported on Jeju by Johnson and Jones (1955) to be a subspecies, A. a. chejuensis. According to Won and Smith (1999), the subspecies of striped field mouse on Jeju was regarded as separate species, A. chejuensis based on Koh and Yoo (1992). But Koh et al. (1998) treated A. chejuensis as a morphologically distinctive insular population of A. agrarius. Striped field mouse populations on both Jeju Island and nearby Wan Island (80 km North from Jeju) were regarded as A. a. chejuensis (Koh et al., 1998). However, based on recent research that compared external and cranial morphological characters, Oh et al. (2003) treats A. $a$. chejuensis as a separate species, Apodemus chejuensis. And Oh and Mori(1998) revealed reproductive isolation judging that a reproductive barrier existed between the two local populations because the reproduction success rate was very low in the crosses between the 2 subspecies or the first generation and parents through crossbreeding experiments to test reproductive compatibility between 2 subspecies, Apodemus agrarius coreae from the Korean mainland and Apodemus agrarius chejuensis from Jeju Island.

The striped field mouse is the most abundant rodent on Jeju and inhabits various habitats from grassland, hills, and shrub forest, to the top of Halla-san.

\section{Micromys minutus hertigi, Jeju Harvest Mouse}

According to Jones and Johnson (1965), Korea has 2 subspecies of old world harvest mouse, M. m. ussuricus on Korean peninsula and M. m. hertigi on Jeju.

General habitat for this species on Jeju is grassland of low-lying ground, riparian habitats with sedges or grasses and silver grass community of middle mountainous area. This mouse is distributed from lowlands to mountainous areas up to $1,200 \mathrm{~m}$.

\section{Mus musculus mollossinus, House Mouse}

The house mouse on Jeju was regarded as M. m. yamashinai, as with the Korean peninsula population (Won, 1968). The main competitor of the house mouse is Rattus norvegicus and interiors of human construction are preferred habitat for both species (Won, 1967). Most small mammal surveys on Jeju are conducted in suburban or forested areas, and therefore, house mice are rarely captured (Oh et al., 2007).

\section{Rattus norvegicus, Brown Rat}

The brown rat is distributed from Korean peninsula to Jeju. The Korean population is regarded as $R$. n. caraco and was considered as a native mammal in Korea (Won and Smith, 1999). However, brown rat is listed on wien species (NIER, 2011). This species inhabits all human habitations, from urban area to temples in mountains. The population density on Jeju is relatively low.

\section{Rattus rattus, Roof Rat}

The subspecific status of the roof rat on Jeju is uncertain (Won and Smith, 1999). Although, similar to the brown rat, the roof rat inhabits human habitations, $R$. rattus is limited to port areas by $R$. norvegicus (Won, 1967). Unlike the house mouse and brown rat, the roof rat is non-native on Jeju and was introduced (Won and Smith, 1999). 
Table 3. Terrestrial mammals on Jeju Island.

\begin{tabular}{|c|c|}
\hline Species & Remark \\
\hline \multicolumn{2}{|l|}{ Order Soricomorpha } \\
\hline \multicolumn{2}{|l|}{ Family Soricidae } \\
\hline Sorex caecutiens hallamontanus, Jeju Shrew & $\mathrm{E}$ \\
\hline \multicolumn{2}{|l|}{ Crocidura shantungensis, Asian Lesser White-Toothed Shrew } \\
\hline \multicolumn{2}{|l|}{ Order Chiroptera } \\
\hline \multicolumn{2}{|l|}{ Family Rhinolophidae } \\
\hline \multicolumn{2}{|l|}{ Rhinolophus ferrumequinum quelpartis, Greater Horseshoe Bat } \\
\hline \multicolumn{2}{|l|}{ Family Vespertilionidae } \\
\hline \multicolumn{2}{|l|}{ Pipistrellus abramus, Japanese Pipistrelle } \\
\hline \multicolumn{2}{|l|}{ Hypsugo alaschanicus coreensis, Alashanian Pipistrelle } \\
\hline \multicolumn{2}{|l|}{ Myotis bombinus, Far Eastern Myotis } \\
\hline \multicolumn{2}{|l|}{ Myotis branditii, Brandt's Myotis } \\
\hline \multicolumn{2}{|l|}{ Myotis daubentonii, Daubenton's Myotis } \\
\hline \multicolumn{2}{|l|}{ Myotis formosus, Hodgson's Myotis } \\
\hline \multicolumn{2}{|l|}{ Myotis ikonnikovi, Ikonnikov's Myotis } \\
\hline \multicolumn{2}{|l|}{ Myotis macrodactylus, Big-footed Myotis } \\
\hline \multicolumn{2}{|l|}{ Miniopterus fuscus, Southeast Asian Long-fingered Bat } \\
\hline \multicolumn{2}{|l|}{ Miniopterus schreibersii fuliginosus, Schreibers's Long-fingered Bat } \\
\hline \multicolumn{2}{|l|}{ Murina leucogaster, Greater Tube-nosed Bat } \\
\hline \multicolumn{2}{|l|}{ Order Carnivora } \\
\hline \multicolumn{2}{|l|}{ Family Mustelidae } \\
\hline \multicolumn{2}{|l|}{ Meles leucurus, Asian Badger } \\
\hline Mustela sibirica quelpartis, Jeju Weasel & $\mathrm{E}$ \\
\hline \multicolumn{2}{|l|}{ Order Artiodactyla } \\
\hline \multicolumn{2}{|l|}{ Family Suidae } \\
\hline Sus scrofa, Wild Boar & A \\
\hline \multicolumn{2}{|l|}{ Family Cervidae } \\
\hline \multicolumn{2}{|l|}{ Capreolus pygargus tianschanicus, Siberian Roe } \\
\hline Cervus nippon, Sika & A \\
\hline \multicolumn{2}{|l|}{ Order Rodentia } \\
\hline Family Sciuridae & \\
\hline Sciurus vulgaris, Eurasian Red Squirrel & A \\
\hline Tamias sibiricus, Siberian Chipmunk & A \\
\hline Family Cricetidae & \\
\hline Tscherskia triton, Greater Long-tailed Hamster & \\
\hline Family Muridae & \\
\hline Apodemus chejuensis, Jeju Striped Field Mouse & $\mathrm{E}$ \\
\hline Micromys minutus hertigi, Jeju Harvest Mouse & $\mathrm{E}$ \\
\hline Mus musculus mollossinus, House Mouse & \\
\hline Rattus norvegicus, Brown Rat & \\
\hline Rattus rattus, Roof Rat & \\
\hline Family Myocastoridae & \\
\hline Myocastor coypus, Coypu or Nutria & A \\
\hline
\end{tabular}

Key: E, endemic species; EN, endangered species; A, invasive alien species

Family Myocastoridae

\section{Myocastor coypus, Coypu or Nutria}

Even though nutria has been known as invasive alien species especially around southern Korean peninsula, Jeju had remained nutria free. The feral nutria occurrence on Jeju is a major concern. Four individuals occurred on Southern wetland in 2011. Because there are several Nutria farms on Jeju, it will be necessary to ensure accidental or intentional releases do not occur.

According to national list of Korean mammals (NIBR,
2012), 71 species of terrestrial mammals are listed as present on the Korean peninsula, and 28 species occur on Jeju Island (Table 3). With 5 species of invasive mammals (Sus scrofa, Cervus nippon, Sciurus vulgaris, Tamias sibiricus and Myocastor coypus), Jeju has 1 endemic species (Apodemus chejuensis) and 3 subspecies (Sorex caecutiens hallamontanus, Mustela sibirica quelpartis and Micromys minutes hertigi). Also, the subspecific level of white-toothed shrew (Crocidura sp) on Jeju is not clear. Compared to the Korean peninsula, which has 1 endemic mammal (NIBR, 2011), the number of endemic mammals on Jeju is quite large. Conservation of this 
island's endemism is an important priority (Van Dyke, 2008).

\section{REFERENCES}

Abramov, A.V. 2001. Notes on the taxonomy of the Siberian badgers (Mustelidae: Meles). Proceeding of the Zoological Institute Russian Academy of Science 288:211-233 (in Russian).

Corbet, G.B. 1978. The mammals of the Palaearctic Region: a Taxonomic Review. British Museum (Natural History).

Horacek, I., V. Hanak and J. Gaisler. 2000. Bats of the Palearctic region: A taxonomic and biogeographic review: in Proceedings of the VIIIth European bat research symposium. Vol. I. Approaches to biogeography and ecology of bats. Institute of Systematics and Evolution of Animals PAS in Krakow, Poland.

Iwasa, M.A., S. Ohdachi, S.H. Han, H.S. Oh, H. Abe and H. Suzuki. 2001. Karyotype and RFLP of the nuclear rDNA of Crocidura sp. On Cheju Island, South Korea (Mammalia, Insectivora). Mammalia 65:451-459.

Jameson, E.W. and G.S. Jones. 1977. The Soricidae of Taiwan. Proceedings of Biological Society of Washington 90:459-482.

Johnson, D.H. and J.K. Jones Jr. 1955. Three new rodents of the Genera Micromys and Apodemus from Korea. Proceeding of Biological Society of Washington 58:167-174.

Jones, J.K. Jr. and D.H. Johnson. 1965. Synopsis of the lagomorphs and rodents of Korea. University Kansas Publications.

Kawai, K., M. Nikaido, M. Harada, S. Matsumura, L.K. Lin, Y. Wu, M. Hasegawa and N. Okada. 2003. The status of the Japanese and East Asian bats of the genus Myotis (Vespertilionidae) based on mitochondrial sequences. Molecular Phylogenetics and Evolution 28:297-307.

Kishida, K. and T. Mori. 1931. Distribution of land mammals of Korea. Zoological Magazine 43:372-391 (in Japanese).

Koh, H.S. and B.G. Yang. 2000. Diversity of mitochondrial DNA cytochrome b gene in roe deer (Capreolus pygargus tianschanicus Satunin) from Jejudo Island, Korea. Animal Systematics, Evolution and Diversity 16:169-176.

Koh, H.S. and B.S. Yoo. 1992. Variation of mitochondrial DNA in two subspecies of striped field mice, Apodemus agrarius coreae and Apodemus agrarius chejuensis, from Korea. Korean Journal of Zoology 35:332-338.

Koh, H.S., G. Csorba, M.P. Tiunov and G. Tikhonova. 1998. Morphometric Analysis of the Three Subspecies of Striped Field Mouse, Apdemus agrarius Pallas (Mammalia: Rodentia) from Far Eastern Asia: Taxonomic Status of North Korean Striped Field Mice. The Korean Journal of Systematic Zoology 14:327-334.

Koopman, K.F. 1993. Order Chiroptera: in Mammal species of the world, a taxonomic and geographic reference, Se- cond Edition. Smithsonian Institution Press.

Kuroda, N. 1934. Korean mammals preserved in the collection of Marquis Yamashian. Journal of Mammalogy 15: 229-239.

Mori, T. 1928. Introduction of terrestrial mammals on Jeju. Korean Education 10:55-60.

Motokawa, M., L.K. Lin, M. Harada and S. Hattori. 2003. Morphometric Geographic Variation in the Asian Lesser White-Toothed Shrew Crocidura shantungensis (Mammalia, Insectivora) in East Asia. Zoological Science 20: 789-795.

National Institute of Biological Resources. 2011. Endemic Species of Korea. NIBR, Korea (in Korean).

National Institute of Biological Resources. 2012. National List of Species of Korea (Vertebrates). NIBR, Korea.

National Institute of Environmental Research. 2011. Alien Species in Korea. NIER, Korea (in Korean).

Oh, H.S. 2002. Mammals of Halla-san National Park: in Report of Hallasan National Park Natural Resources Survey (in Korean).

Oh, H.S. 2006a. Distribution of invasive species and Management. Jeju Regional Environmental Technology Development Center (in Korean).

Oh, H.S. 2006b. Mammals of Halla-san natural reserve: in Report of survey and study of Hallasan natural reserve. Jeju Special Self-Governing province (in Korean).

Oh, H.S. and T. Mori. 1998. Reproduction, growth and development of the striped field mouse, Apodemus agrarius chejuensis. Honyurui Kagaku (Mammalian Science) 38: 23-37 (in Japanese).

Oh, H.S., M.H. Chang and B.S. Kim. 2007. Current status of mammals in Halla-san National Park. Korean Journal of the Env. Eco 21:235-242 (in Korean).

Oh, H.S., Y. Yoshinaga, T. Kaneko, H. Iida and T. Mori. 2003. Taxonomic re-examination of the Apodemus agrarius chejuensis, comparing external and cranial morphological characters among four Asian Apodemus species. Journal of the Faculty of Agriculture, Kyushu University 47:373-386.

Oh, J.G., Y.D. Lee, S.H. Koh, H.J. Koh, S.C. Hyeon, I.B. Kang and C.S. Kim. 2011. Investigation of Home Range on Roe deer in Jeju, Korea. National Institute of Biological Resources.

Ohdachi, S.D., H. Abe and S.H. Han. 2003. Phylogenetical positions of Sorex sp. (Insectivora, Mammalia) from Cheju Island and $\mathrm{S}$. caecutiens from the Korean peninsula, inferred from mitochondrial cytochrome $b$ gene sequences. Zoological Science 20:91-95.

Ohdachi, S.D., H. Abe, H.S. Oh and S.H. Han. 2005. Morphological relationships among populations in the Sorex caecutiens/Shinto group (Eulipotyphla, Soricidae) in East Asian, with a description of a new subspecies from Cheju Island, Korea. Mammalian Biology 70:345-358.

Park, H.S. 1974. A study of the phase of mammal in Jeju 
Island. Bulletin of Cheju University 3:147-159.

Park, H.S. 1985. Report of survey and study of Halla-san natural reserve. Jeju Special Self-Governing Province (in Korean).

Sim, J.H. 1986. A study on the genetic and morphological variation in natural populations of the horse-shoe bat $(R h i$ nolophus ferrumequinum) in Korea. MSc Thesis, Inha University (in Korean).

Son, S.W. and B.J. Choi. 2001. Bats: Jiseong Natural History Series 3. Jiseongsa.

Thomas, O. 1906. List of small mammals from Korea and Quelpart. Proceedings of the Zoological Society, London. pp. 858-865.

Thomas, O. 1908. List of small mammals from the Tsushima Island. Proceedings of the Zoological Society, London. pp. $47-54$.

UNESCO. 2012a. Jeju Volcanic Island and Lava Tube UNESCO World Heritage Center [Available from: http:// whc.unesco.org/en/list/1264/, accessed 20 July 2012].

UNESCO. 2012b. MAB Biosphere Reserve Directory [Available from: http://www.unesco.org/mabdb/br/brdir/direc tory/biores.asp? mode $=$ all $\&$ code $=\mathrm{ROK}+02$, accessed 20 July 2012].

Van Dyke, F. 2008. Conservation Biology: Foundations, Concepts, Applications, Second Edition. Springer.

Wilson, D.E. and D.M. Reeder. 2005. Mammal Species of the World: A taxonomic and Geographic Reference, Third
Edition. Johns Hopkins University Press.

Won, B.H. 1967. Illustrated Encyclopedia of Fauna and Flora of Korea Volume 7, Mammals. Ministry of Education (in Korean).

Won, B.O. and H.C. Woo. 1958. Mammals of Cheju Island. Journal of Applied Zoology 1:5-13 (in Korean).

Won, C.M. and K. Smith. 1999. History and current status of mammals of the Korean peninsula. Mammal Review 29: 1-33.

Won, H.K. 1968. The Mammals of Korea. Institute of Science Press (in Korean).

Yoon, M.H. 2010. Vertebrate Fauna of Korea Volume 5, Number 1, Bats. National Institute of Biological Resources.

Yoon, M.H. and S.W. Son. 1989. Studies on taxonomy and phylogeny of bats inhabiting Korea 1. taxonomical review of one Rhinolophid and Six Vespertilionid bats, and the Korean microchiropteran faunal succession. Korean Journal of Zoology 32:375-392.

Yoon, M.H., S.H. Han, H.S. Oh and J.K. Kim. 2002. The Mammals of Korea. Dongbang Media (in Korean).

Yoshiyuki, M. 1989. A systematic study of the Japanese Chiroptera. National Science Museum.

Submitted: July 26, 2012, Accepted: August 24, 2012 